\title{
Perbandingan Metode Spektrofotometri UV Dan HPLC pada Penetapan Kadar Kafein dalam Kopi
}

\author{
Hari Susanti*, Nisa Putri Mujaadillah Araaf, Dede Gunanto, Aprilia Kusbandari \\ Fakultas Farmasi Universitas Ahmad Dahlan \\ *Email korespondensi : hari.susanti@pharm.uad.ac.id
}

(Submit 15/03/2019, Revisi 05/09/2019, Diterima 20/12/2019)

\begin{abstract}
Abstrak
Kafein merupakan salah satu alkaloid yang terkandung dalam kopi. Konsumsi kafein dalam jumlah besar bisa berdampak pada kesehatan manusia. Kebiasaan orang-orang jamun dulu minum kopi tradisional, maupun orang jaman sekarang minum kopi dengan berbagai varian tentu akan berpengaruh pada kondisi kesehatan. Sehingga perlu diketahui kandungan kafein dalam kopi. Peneliti terdahulu telah melakukan penetapan kadar kopi dengan metode HPLC maupun Spektrofotometri. Namun belum ada yang membandingkan kedua metode. Penelitian ini bertujuan untuk membandingkan metode spektrofotometri UV dan HPLC dalam penetapan kadar kafein dalam kopi. Sampel yang digunakan adalah sediaan kopi hijau dan kopi hitam. Perbandingan metode dilakukan dengan membandingkan data hasil validasi metode antara spektrofotometri UV dan HPLC. Metode spektrofotometri dilakukan dengan pelarut air, absorbansi kafein dibaca pada panjang gelombang $272 \mathrm{~nm}$. Metode HPLC dilakukan dengan fase diam C18, fase gerak matanol-air $(69: 40 \mathrm{v} / \mathrm{v})$ flow rate $1 \mathrm{ml} /$ menit dan detector UV $272 \mathrm{~nm}$. Hasil validasi metode analisis kafein secara spektrofotometri adalah sebagai berikut : linearitas $(R=0,9965)$, presisi $(R S D=0,899 \%)$, akurasi (recovery $=98,46 \%) L O D=1,12$ $\mathrm{ug} / \mathrm{ml}, \mathrm{LOQ}=3,75 \mathrm{ug} / \mathrm{ml}$. Hasil validasi metode HPLC adalah: linearitas $(R=0,998)$, Presisi (RSD= 2,49\%), akurasi (Recovery= 84\%), LOD=0,565 ug/ml, LOQ= 1,88 ug/ml. Kadar kafein dalam sampel kopi hijau sediaan dan kopi hitam sediaan, secara Spektrofotometri UV bertrurut-turut (dalam \%) adalah : $(0,155 \pm 0,053)$ dan $(0,696 \pm$ 0,014). Kadar kafein dalam kopi hijau sediaan, kopi hitam sediaan, secara HPLC berturut-turut (dalam \%) adalah ; 0,121 dan 0,421. Metode spektrofotometri UV direkomendasikan sebagai metode pilihan pada penetapan kadar kafein dalam sampel kopi.
\end{abstract}

Kata kunci: Spektrofotometri UV, HPLC, kafein, kopi

\section{Outline}

- Pendahuluan

- Metode

- Hasil dan Pembahasan

- Kesimpulan

- Ucapan Terima Kasih

- Daftar Pustaka 


\section{Pendahuluan}

Kopi merupakan salah satu minuman yang sangat sering dikonsumsi oleh seluruh masyarakat dunia.. Namun perlu menjadi perhatian dalam hal mengkonsumsi kopi, karena kafein yang terkandung dalam kopi mampu untuk meningkatkan terjadinya penyakit jantung, LDL serta meningkatkan tekanan darah jangka pendek (Freedman et al, 2012). Penikmat kopi biasanya meminum kopi 3-4 kali sehari (Maramis, dkk., 2013). Salah satu senyawa yang terkandung dalam kopi adalah kafein (gambar 1) (Mulato, 2001). Untuk menjamin keamanan kopi yang beredar di pasaran, Badan Standarisasi Nasional (BSN) telah menetapkan standar untuk kadar kafein dalam kopi berkisar 0,45$2 \%$ b/b (SNI 01-3542-2004). Sehingga jika ada kopi yang mengandung kadar kafein yang tinggi perlu dilakukan dekafeinisasi, untuk menekan aktivitas kafein di dalam tubuh (Sofiana, 2011).

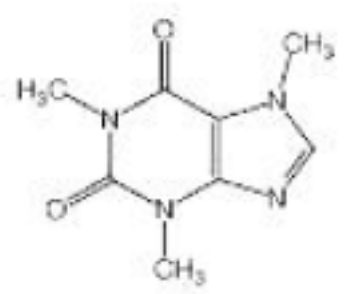

Gambar 1. Struktur kimia kafein

Saat ini, banyak metode analisis yang telah dikembangkan untuk menetapkan kadar kafein seperti titrimetri, spektrofotometri, Gas chromatography (GC), NIRS dan Mass Spektroskopi. Namun, sebagian besar metode di laporkan memiliki banyak masalah dalam hal deteksinya (Chowdhurry et al, 2012). Berdasarkan penelitian Arwangga, dkk., (2016) dalam menetapkan kadar kafein pada kopi dengan metode sperktofotometri UVVis. Dari beberapa metode tersebut, metode HPLC merupakan metode yang paling selektiv dalam memisahkan senyawa yang terkandung dalam kopi. Berdasarkan uraian diatas, peneliti tertarik untuk menetapkan kadar kafein dalam kopi metode spekstrofotometri UV dan HPLC.

\section{Metode}

\section{A. Bahan}

Bahan yang digunakan adalah sediaan kopi hijau dan kopi hitam, Kloroform, $\mathrm{NH}_{4} \mathrm{OH}$, $\mathrm{CaCO}$, pereaksi Mayer, pereaksi Wagner, pereaksi Dragendorf, pereaksi Parry dan Pereaksi Mureksid. Metanol for HPLC, aquabidest

\section{B. Alat}

Alat alat yang digunakan dalam penelitian antara lain glassware, neraca analitik EXT 200 (Ohaus), HPLC Shimadzu LC 20 AT, kolom LiChrospher® 100 RP-18 endcapped $(5 \mu \mathrm{m})$ panjang $25 \mathrm{~cm}$, diameter dalam $4 \mathrm{~mm}$ (E. Merck), Spektrofotometer Pharmaspec UV 1800 (Shimadzu)

\section{Prosedur Penelitian}

1. Pengumpulan Sampel

Sampel kopi hitam dan kopi hijau siap seduh yang digunakan adalah kopi yang banyak beredar di pasaran. 
2. Analisis Kualitatif

a. Uji Parry

Analisis metode Parry dilakukan dengan cara sejumlah zat dilarutkan dalam alkohol, kemudian ditambahkan reagen Parry dan ammonia encer. Larutan berwarna biru tua/hijau menyatakan terdapat kafein (DepKes, 1995).

b. Uji Dragendorff

Sebanyak $1 \mathrm{~g}$ sampel dilarutkan dalam $10 \mathrm{ml}$ kloroform dan 4 tetes $\mathrm{NH}_{4} \mathrm{OH}$, kemudian disaring dan filtratnya dimasukkan ke dalam tabung reaksi bertutup. Ekstrak kloroform dalam tabung reaksi dikocok dengan $6 \mathrm{ml} \mathrm{H}_{2} \mathrm{SO} 42 \mathrm{M}$ dan lapisan asamnya dipisahkan ke dalam tabung reaksi yang lain ditambah 3 tetes larutan Dragendorf yang akan menimbulkan endapan warna merah jingga (Harborne 1987).

c. Uji kualitatif dengan membandingkan tR standar kafein dengan sampel serta membandingkan spectra sampel dengan spectra standar kafein pada spektrofotometer UV.

3. Validasi metode Spektrofotometri UV

a. Penentuan Spesifisitas

Dibuat larutan strandar kafein $5 \mu \mathrm{g} / \mathrm{ml}$ dalam akuades. Discan panjang gelombang dari $200-300 \mathrm{~nm}$. Larutan sampel hasil ekstraksi discan panjang gelombang dari 200-300 nm. Dilihat kesesuaian profil spektra.

b. Penentuan linearitas

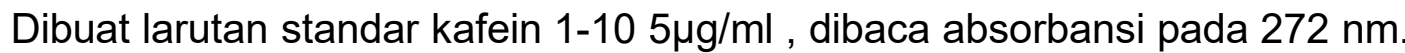

Dibuat kurva regresi antara konsentrasi vs absorbansi

c. Penentuan akurasi

Tambahkan sejumlah standar kafein yang setara dengan $80-120 \%$ dari kadar kafein dalam sampel, perlakukan seperti preparasi sample. Hitung $\%$ recovery.

4. Validasi Metode analisis HPLC

a. Instrumentasi dan kondisi kromatografi

Kolom yang digunakan $\mathrm{C} 18$, resistensi pH $(4.5 \mathrm{~mm} \times 250 \mathrm{~nm} ; 5 \mathrm{um})$. Detector di atur pada $272 \mathrm{~nm}$ dan run time 20 menit dengan flowrate $1 \mathrm{ml} / \mathrm{menit}$ dalam suhu ruangan

b. Pemilihan Fase gerak

Kombinasi antara air dan methanol grade HPLC dengan rasio 60:40 menggunakan flow rate $1 \mathrm{ml} /$ menit dan run time di atur 8 menit.

c. Linearitas

Timbang kafein $20 \mathrm{mg}$ kemudian larutkan dengan aquadest sampai $100 \mathrm{ml}$ (larutan stok). Untuk linearita, ambil larutan stok dengan 3 sampai $7 \mathrm{ml}$ larutkan dalam 50 dengan konsentrasi $12-28 \mathrm{ug} / \mathrm{ml}$ dan gunakanlah kalibrasi.

d. Presisi

Larutan standar kafein konsentrasi 16, 20 dan 24 ug/ml diinjeksikan ke dalam HPLC (replikasi 3 kali). Dihitung \% RSD.

e. Akurasi

Dalam penelitian ini menggunakan konsentrasi $80 \%, 100 \%, 120 \%$ kafein larutkan dalam $100 \mathrm{ml}$ aquadest. Larutan di analisis dengan HPLC $272 \mathrm{~nm}$. Prosedur ini di replikasi sebanyak $3 x$.

f. LOD dan LOQ

Limit of detection (LOD) and Limit of quantification (LOQ) menggunakan persamaan $\mathrm{LOD}=3.3 \times \mathrm{s} 0 / \mathrm{b} \quad \mathrm{LOQ}=10 \times \mathrm{s} 0 / \mathrm{b}$

Dimana S0 dan b merupakan SD dan Slope dari garis kalibrasi. 
g. Preparasi sampel

Sebanyak 1 gram bubuk kopi dimasukkan ke dalam gelas piala kemudian ditambahkan $150 \mathrm{~mL}$ akuades panas kedalamnya sambil diaduk. Larutan kopi panas disaring melalui corong dengan kertas saring ke dalam Erlenmeyer, kemudian $1,5 \mathrm{~g}$ kalsium karbonat(CaCO3) dan larutan kopi tadi dimasukkan ke dalam orong pisah lalu diekstraksi sebanyak 4 kali, masing-masing dengan penambahan $25 \mathrm{~mL}$ kloroform. Lapisan bawahnya diambil, kemudian ekstrak (fase kloroform) ini diuapkan dengan rotari evaporator hingga kloroform menguap seluruhnya. Ekstrak kafein bebas pelarut dimasukkan ke dalam labu takar $100 \mathrm{~mL}$, diencerkan dengan akuades hingga garis tanda dan dihomogenkan. Larutan kemudian ditentukan kadarnya dengan spektrofotometri UV dan HPLC (Fitri, 2008).

\section{Hasil dan Pembahasan}

Hasil uji kualitatif menunjukkan bahwa semua sampel kopi yang digunakan mengandung alkaloid kafein (tabel 1)

Tabel 1. Rangkuman hasil uji kualitatif

\begin{tabular}{|l|c|c|c|c|}
\hline \multicolumn{1}{|c|}{ Sampel } & \multicolumn{5}{|c|}{ Jenis uji } \\
\cline { 2 - 6 } & Parry & Dragendorf & tR (HPLC) & Spektra \\
\hline Standar kafein & + & + & + & + \\
\hline Kopi hitam & + & + & + & + \\
\hline Kopi Hijau & + & + & + & + \\
\hline
\end{tabular}

Baik secara uji tabung maupun membandingkan tR di HPLC serta spectra pada spektrofotometer, kesemua sampel menunjukkan positif mengandung kafein. Hasil validasi metode analisis kafein secara spektrofotometri UV dan HPLC seperti tersaji pada tabel 2.

Tabel 2. Hasil validasi metode

\begin{tabular}{|c|c|c|}
\hline \multirow{2}{*}{ Parameter } & \multicolumn{2}{|c|}{ Metode } \\
\hline & HPLC & Spektrofotometri UV \\
\hline Linearitas (R) & 0,99807 & 0,9965 \\
\hline Slope: intersep & 49.923,569x; 46.702,389 & $0,0549 X ; 0,1622$ \\
\hline rentang & $1-10$ & $1-15$ \\
\hline LOD/LOq (ug/ml) & $0,565243 / 1,884142$ & $1,12506 / 3,750199$ \\
\hline Presisi (\%RSD) & 2,49 & 0,89 \\
\hline Recovery (\%) & 84,00 & 98,46 \\
\hline
\end{tabular}

Berdasar data pada tabel 2 terlihat bahwa baik metode HPLC maupun spektrofotometri UV memiliki linearitas yang baik dan memenuhi persyaratan FDA (Snyder et al, 2000) metode HPLC memiliki sensitifitas yang lebih baik dibanding spektrofotometri UV. Hal ini terlihat dari nilai LOD dan LOQ yang lebih rendah. Metode spektrofotometri memiliki nilai presisi dan akurasi yang memenuhi syarat dan lebih baik dibanding HPLC. Dari keseluruhan hasil validasi, dalam penelitian ini lebih direkomendasikan metode spektrofotometri UV. Selain lebih mudah, murah, ternyata memiliki parameter validasi yang lebih baik dibandingkan HPLC, terutaman dalam akurasi metode. 
Hasil penetapan kadar kafein dalam sampel

Penetapan kafein dalam sampel didahului dengan ekstraksi kandungan kafein dalam sampel. Ekstraksi dilakukan dengan membuat suasana basa pada suspense sampel dalam air. Hal ini bertujuan untuk melkukan salating out domana kafein dalam kopi biasanya berada dalam bentuk garam diubah menjadi dalam bentuk basa. Ekstraksi selanjutnya dilakukan dengan pelarut kloroform untuk mengambil kafein (base) yang bersifat larut kloroform. Hasil penetapan kadar kafein dalam sampel dengan metode HPLC dan spektrofotometri UV tersaji pada tabel 3.

Tabel 3. Hasil penetapan kadar kafein dalam sampel

\begin{tabular}{|l|l|l|}
\multicolumn{1}{|c|}{ Sampel } & \multicolumn{3}{c|}{ KPLC } & \multicolumn{1}{c|}{ Spektrofotometri UV } \\
\hline Kopi hijau sediaan & $0,121 \pm 4,815$ & $0,155 \pm 0,053$ \\
\hline Kopi hitam sediaan & $0,421 \pm 4,51$ & $0,696 \pm 0,014$ \\
\hline *Data dinyatakan dalam rata-rata \pm SD &
\end{tabular}

Dari hasil penelitian (tabel 3) terlihat bahwa kadar kafein pada sampel kopi hitam lebih tinggi daripada kopi hijau, baik secara HPLC maupun spektrofotometri UV.

\section{Kesimpulan}

Hasil validasi metode analisis kafein secara spektrofotometri adalah sebagai berikut : linearitas $(R=0,9965)$, presisi $(R S D=0,899 \%)$, akurasi (recovery $=98,46 \%) L O D=1,12$ $\mathrm{ug} / \mathrm{ml}, \mathrm{LOQ}=3,75 \mathrm{ug} / \mathrm{ml}$. Hasil validasi metode HPLC adalah: linearitas $(\mathrm{R}=0,998)$, Presisi $(R S D=2,49 \%)$, akurasi (Recovery= 84\%), LOD=0,565 ug/ml, LOQ= 1,88 ug/ml. Kadar kafein dalam sampel kopi hijau sediaan dan kopi hitam sediaan, secara Spektrofotometri UV bertrurut-turut (dalam \%) adalah : $(0,155 \pm 0,053)$ dan $(0,696 \pm$ $0,014)$. Kadar kafein dalam kopi hijau sediaan, kopi hitam sediaan, secara HPLC berturut-turut (dalam \%) adalah ; 0,121 dan 0,421. Metode spektrofotometri UV direkomendasikan sebagai metode pilihan pada penetapan kadar kafein dalam sampel kopi

\section{Ucapan Terima Kasih}

Penulis mengucapkan terimakasih kepada LPP UAD yang telah menyediakan dana penelitian ini dengan skim Hibah penelitian Fundamental.

\section{Daftar Pustaka}

1. Chowdhury, Sharmin Reza., Maleque, Mahfuza., and Shihan, Mahbubul hoque,. 2012, Development and Validation of a Simple RP-HPLC Method for Determination of Caffeine in Pharmaceutical Dosage Forms. University of Bangladesh

2. Dalimartha, S.2000. Atlas Tumbuhan Obat Indonesia. Trubus Agrowidya. Bogor

3. Ditjend POM. 1989. Materia Medica Indonesia.Jilid kelima.DepKes RI, Jakarta.Hal.534-540.

4. $\quad$ Dirjen POM. 1979. Farmakope Indonesia.Edisi ketiga. DepKes RI. Jakarta

5. Fridewald, NT., RI Levy, RI Frieddericson. 2001. Estimation Of The Concentration Of Low Density Lipoprotein Cholesterol Plasma Without Use The Prepagative 
Ultracentrifugation. Clinical Chemistry 1972: 18; 499-502

6. Harborne, J. B. 1996. Metode Fitokimia Penuntun Cara Menganalisis Tumbuhan. Terjemahan Padmawiyata, K., dan Soediro, I. ITB. Bandung. Hal.69-94

7. Jackman, R. L. Dan Smith, J. L. 1996. Anthocyanins and Betalains.Natural Food Colorants.Second Edition.Chapman and Hall. London. Hal.183-241

8. Kumar, vinay.Cotran, Ramzi S. Robbins, Stanley L. 1997.Robbins Basic Pathology Edition $7^{\text {th }}$. USA: Saunders

9. Lee, M. P., Abdullah, R. Dan Hung, K. L. 2011.Thermal Degradation of Blue Anthocyanin Extract of Clitoria termatea Flower.International Conference on Biotechnology and Food Science IPCBEE. 7:49-53

10. Maramis, R.K.,, Citaningtyas, G., Wehantouw ,F., 2013, Analisis Kafein dalam kopi bubuk di kota Manado Menggunakan Spektrofotometri UV-Vis, Pharmacon, Vol 2 No 4: $122-128$

11. Muntiha, M. 2001. Teknik Pembuatan Preparat Histopatologi Dari Jaringan Hewan Dengan Pewarnaan Hemaktosilin dan Eosin (H\&E). Balai Penelitian Veteriner. Bogor

12. Price, Sylvia A. Wilson, Lorraine M. 2005.Patofisiologi: Konsep Klinis Prosesproses penyakit. Jakarta: EGC

13. Sari, P. Agustina. F., Komar, M., Unus, Fauzi., M., dan Lindriati, T. 2005. Ekstraksi dan Stabilitas Antosianin Dari Kulit Buah Duwet (Syzgium cumini).Jurnal Teknol. dan Industri Pangan. XVI (2): 142-146

14. Sirait, A M. 2001. Analisa Varians (ANOVA) dalam Penelitian Kesehatan. Jurnal Media Litbang Kesehatan. Vol XI No 2 P:39-43. 